\title{
VOLUNTARY POOLING IN CANADIAN OIL AND GAS LAW
}

\section{WILLIAM H. ANGUS}

Two recent cases have thrust the concept of pooling freehold lands in oil and gas law into the limelight for the first time in Canada. ${ }^{1}$ Our courts have been in the enviable position of breaking new ground and rendering decisions which undoubtedly will shape the future of pooling in this country. It would seem worthwhile therefore to examine these first steps. ${ }^{2}$

\section{The Concept of Pooling}

Pooling is not of course an abstract unrelated idea. It serves many purposes. From a conservation point of view it is but a part of a broader concept, that of maximum recovery from a subsurface oil and gas reservoir." To achieve this object, it is necessary to consider the oil and gas reservoir as a whole. Unfortunately the conservation approach does not coincide with the prevailing rule of capture." This latter principle was established early in the development of oil and gas law, its chief merit being convenience." It dictates that the party who reduces oil and gas to surface possession on his land will be recognized as owner nothwithstanding the fact that the oil and gas so recovered has been drained from underneath the surface of an adjoining or neighbouring property owner. A premium is thus placed on drilling and producing oil and gas as fast as possible so as to recover the substances underneath one's own property in self-defence and also drain adjoining lands if possible. Although normally a landowner is entitled to the minerals in place beneath his surface, presuming that they are not expressly reserved or owned by someone else, where oil and gas is concerned the nature of these substances and the anarchic rule of capture lead to an unusual exception. A landowner may lose the oil and gas in place beneath his surface by drainage and have no legal recourse against the party who reduced it to possession on neighbouring land.

As a consequence, United States courts have come to the rescue of a lessor by imposing upon the lessee an implied convenant to protect against drainage. ${ }^{6}$ The lessee must therefore either drill an offset well on the lessor's land to prevent

-William H. Angus, B.A., LL.B. (Toronto), LL.M. (Columbia), Assistant Professor, Faculty of Law, University of Alberta.

1Shell Oil Company v. Gunderson [1960] S.C.R. 424, on appeal from (1959) 28 W.W.R. 506 (Alta. C.A.); Shell Oil Company v. Gibbard (1961) 26 D.L.R. (2d) 400, (1961) 34 W.W.R. 117 (Alta. C.A.).

${ }^{2}$ Consideration is given here to pooling under freehold leases only and no attempt is made to examine situations where Crown leases are involved.

9An introduction to principles of oil and gas conservation is given in Williams, Maxwell and Meyers, Cases and Materials on the Law of Oil and Gas (1956) c. 3, p. 76 et seq. For a discussion of some of the technical aspects of petroleum reservoirs, see Murphy (ed.), Conservation of Oil \& Gas (1949) c. 1, p. 3 et seq.

SOn the rule of capture, see Myers, The Law of Pooling and Unitization (1957) p. 18 et seq., and Williams et al, op. cit., supra, footnote 3 , at p. 77.

oMyers, op. cit, supra, footnote 4, at p. 19, notes that: "Another explanation for the origin of the law is the fact that there was no way of ascertaining with any degree of accuracy the origin of the oil or gas that was produced from a well.".

'On this covenant see Merrill, Covenants Implied in Oil and Gas Leases (2nd ed., 1940), c. $V$, p. 232 et seg. Concerning implied ccvenants generally in Canada, see Lewis and Thompson, Canadian Oil and Gas (current) vol I, div. A, §121. 
drainage or risk payment of damages which may well be measured by speculative loss.' There is a particular hardship where the lessee also holds a lease in respect of adjoining property on which a producing well is draining the lessor's land. The lessee in this situation must pay a royalty to the adjoining landowner which includes royalty on the oil and gas drained from the lessor's land while remaining liable to the lessor for loss of this royalty or even speculative damages. In effect the lessee finds himself obligated to pay a double royalty at least. To drill an offset well instead would involve him in needless drilling expense since he can efficiently drain the whole reservoir with the one well on the adjoining land. It was specifically to meet this and related problems that a pooling clause was inserted in the lease. Lands under two or more leases may be pooled together so that one producing well anywhere on the pooled lands will be deemed production under each lease and the royalty will be apportioned to each lessor on a prearranged basis."

Pooling is also commonly employed to meet spacing requirements for drilling and production laid down under oil and gas conservation statutes. ${ }^{10}$ In many of these situations, the leases for lands within a prescribed spacing unit will be held by different lessees. This may raise a number of complex problems. Providing that all the leases contain a suitable pooling provision, the lessees may pool by mutual agreement. In other instances however, some lessees for reasons of their own will not wish to pool, or their leases will not contain adequate pooling provisions in the situation. It is in this type of circumstance, where voluntary pooling has broken down or is inapplicable, that most conservation statutes step in and provide machinery for compulsory pooling."

Voluntary pooling is to be contrasted to compulsory pooling. ${ }^{12}$ In the former, pooling takes place at the will of one or both of the parties to a lease. It goes without saying that if a lessor and lessee should mutually agree to pooling, there is no problem. Almost all freehold oil and gas leases now contain a pooling provision permitting the lessee to pool in his discretion under cartain terms and subject to certain conditions. The parties have thus agreed to pooling in advance. It is not open to the lessor, having so agreed, to object when the lessee actually initiates pooling proceedings. Pooling in this manner is of course dependant upon the relevant lease provisions. It is obvious that

ispeculative loss takes into account the fact that the lessor might have sold his royalty interest at an inflated value when and if drilling operations had been commenced. Specula. tive damages were awarded in Albrecht v. Imperial Oil Limiled (1957) 21 W.W.R. 560 (Alza.). There is dispute in some quarters as to whether speculative loss should be recognized by the courts.

sThis was the situation in Albrecht v. Imperical Oil Limited, supra, footnote 7, but instead of an implied covenant, the lease in that case contained an express provision for protection against drainage.

"It will be apparent that the basis for sharing royalties among lessors will be of considerable importance. Ordinarily the amount of acreage included in the pooled unit is the measure. Inequities may result however where only a small portion of one lessor's acreage is actually over the o:l and gas resevoir but the whole of his lands are pooled in the unit. Other difficulties also accompany apportionment on an acreage basis.

${ }^{10}$ Conservation statutes are in force in the provinces of Alberta, British Columbia, Manitoba, Ontario and Saskatchewan. Ontario was the first to enact such legislation in 1921. Alberta followed suit in 1932 for the Turner Valley field.

"See The Oil and Gas Conservation Act, 1957 (Alta.) c. 63, s. 73, 74 and amendments thereto, for an example.

12Myers, op. cit., supra, footnote 4, at p. 59, discusses situations which do not fall under either voluntary or compulsory pooling. They a:e termed "equitable pooling" and lie somewhere between the voluntary and compulsory categories with characteristics of each. 
the permutations and combinations will be almost innumerable owing to the latitude permitted by agreement between the parties. Voluntary pooling is a rather loose arrangement at best and from a conservation point of view is clearly inadequate. ${ }^{13}$ As a result compulsory pooling pursuant to statute was designed to fill the vacuum and give priority to the conservation point of view nothwithstanding the fact that it conflicts with the interests of the parties to the lease. The problem of resolving these conflicting interests is not an easy one but time appears to have established that the element of compulsion has not worked unfairly and the public interest in conservation has been well served."

We shall be concerned here with voluntary pooling under a pooling provision in a lease. The cases of Shell Oil Company v. Gunderson in the Supreme Court of Canada and Shell Oil Company v. Gibbard in the Supreme Court of Alberta, Appellate Division will be used to illustrate the difficulties inherent in this form of pooling."

\section{Shell Oil Company v. Gunderson}

By a petroleum and natural gas lease dated July 19, 1950 and in consideration of a $\$ 2,500$ bonus payment and royalties reserved in the lease, Shell obtained the right to produce oil and gas from a quarter section of land owned by one Morris. The primary term was to continue for a period of five years or so long as oil and gas were produced from the lands, with a delay rental payable annually throughout the primary term in lieu of production. At no point in the five year period was a well drilled on the lessor's quarter section. Delay rentals were paid prior to the anniversary date in each year of the primary term to keep the lease in force." In 1952 however, Shell drilled a gas well on the northeast quarter of the same section, Morris' land being the southeast quarter. Although this well was capable of production, it was not connected to a gathering system and was therefore capped.

In June of 1955 with the Morris lease about to expire the next month, Shell served a notice dated the 22nd upon Gunderson, executor under the last will and testament of Morris who was by this time deceased, purporting to pool the Morris quarter with the remainder of the section to form a drilling unit as defined in the lease and prescribed by government regulations. ${ }^{17}$ Clause 9 of this lease provided:

"The Lessee is hereby given the riglat and power at any time and from time to time to pool or combine the said lands, or any portion thereof, with orher lands adjoining the said lands, but so that any one such pool or unit (herein referred to as a 'unit') shall not exceed one drilling unit as hereinbefore defined, when such pooling or combining is necessary in order to conform with any regulations or orders of the Government of the Province of Alberta or any other authoritative body, which are now or may hereafeer be in force in relation thereto. In the event of such pooling or combining, the Lessor shall, in lieu of the royalties clsewhere herein specified, receive on production of leased substances from the said unit, only such

13 Some of the inadequacies have been suggested in the previous paragraph.

14Williams et al, op. cit., supra, footnote 3, at p. 84; Myers, op. cit., supra, footnote 4 at p. 208. 1 Sitpra, footnote 1.

1"Canadian Fina Oil L.sd. v. Paschke (1957) 21 W.W.R. 260 (Alta. C.A.), affirming (1956) 19 W.W.R. 184, dictates that payment on the anniversary dace will not be sufficient. Delay rentals must be received by the lessor or his depository on the day before the anniversary date to maintain the lease in good standing. The usual form of lease will expire therefore at midnight between the day before and the anniversary date. It is possible of course to word a lease so as to avoid these difficulties.

1'Note that Shell purported in the notice to form a "drilling unit". The implications of this are discussed in connection with Shell Oil Company v. Gibbard, infra, at p. 489. 
portion of the royalties stipulated as the area of the said lands placed in the unit bears to the total area of lands in such unit. Drilling operations on, or production of leased substances from, any land included in such unit shall have the same effect in continuing this Lease in force and effect during the term hereby granted, or any extension thereof, as to all the said lands, as if such operation or production were upon or from the said lands, or some portion thereof." $1 \mathrm{x}$

Shell tendered a cheque for $\$ 50$ with this notice presumably relying on clause 3 in the lease which stated:

"3. Provided no royalties are otherwise paid hereunder, the Lessee shall pay to the Lessor each year as royalty the sum of Fifty Dollars $(\$ \$ 0.00)$ for all wells on the suid lands where gas only or primaily is found and the same is not used or sold, and while the said royalty is so paid each such well shall be deemed to be a preducing well hereunder."10

Gunderson refused to accept this cheque and did likewise when Shell tendered a further $\$ 50$. by cheque in each succeeding year. Shell then brought the action to determine whether the lease was still in force and effect or whether it had expired in July, 1955 at the end of the primary term. ${ }^{20}$

\section{In The Supreme Court of Canada}

Mr. Justice Martland for the Court pointed out that clause 9 by itself did not appear to extend the primary term of five years in the Gunderson situation." The concluding sentence of this clause states that:

"Drilling operations on, or production of leased substances from, any land included in such unit shall have the same effect in continuing this Lease in force and effect during the term hereby granted, or any extension thereof, as to all the said lands, as if such operation or production were upon or from the said lands, or some portion thereof."

Drilling operations were not in progress on the unit upon expiry of the primary term of the Morris lease nor was there actual production of oil and gas from the unit at that time. There was on the other hand a capped gas well on the northeast quarter of the unit. But clause 9 did not expressly provide that a capped gas well on the unit would extend the primary term.":

At this point, Shell argued that the provisions of clause 3 in conjunction with clause 9 covered the situation. It was contended that the capped well on the northeast quarter was deemed to be a producing well by virtue of the operation of clause 3 , and thus production was to be deemed for the purposes of clause 9 which extended the primary term during "production of leased substances".:" But Mr. Justice Martland noted in reply that clause 3 was restricted in its operation to capped wells "on the said lands". "Said lands" was earlier defined in clause 1 (c) of the lease to mean:

". . ull the lands hereinbefore described or referred to, or. such portion or portions thereof as shall not have beell surrendered."

18[1960] S.C.R. 424, at p. 427; (1959) 28 W.W.R. 506, at p. 509 (Alta. C.A.).

19/bid., at p. 426, and p. 507.

solt will be observed that the question was not directed to the validity of the pooling nor was this latter point decided in the Supreme Court of Canada. The Supreme Court of Alberta, Appellate Division hinted that the pooling mighe be invalid and in Shell Oil Company v. Gibbard which followed, decided that this was the case. See infra, at p. 490.

"1Since his appointment to the Supreme Court of Canada from Alberta in January of 1958, Mr. Justice Martland has delivered judgmene for the Court in almost all oil and gas cases.

21nThe italies are mine. Clause 9 is set forth in full supra, at p. 483.

$=2[1960]$ S.C.R. 424, at p. 429.

"2although the point was not discussed in the Supreme Court of Canada, consider whether the requirement of "production of leased substances" in clause 9 is satisfied by the capped well "deemed to be a producing well" under clause 3 . The point is discussed infra, at p. 487.

24[1960] S.C.R. 424, at p. 426 sets forth the relevant portions of clause 1. They ate perhaps important when read togecher as will be seen shortly. 
The "lands hereinbefore described" in the Morris lease werc of course the soucheast quarter belonging to Morris. Since the capped well was not located on the Morris lands and clause 3 was interpreted to be applicable only to a capped well on the Morris lands, it was held that clause 3 could not be invoked in this situation. ${ }^{23}$ Shell answered this view by contending that the pooling notice of June 22, 1955 served to change the meaning of "said lands" in clausz 3 thereafter to include the whole section." This argument assumes that the pooling itself was valid and its validity was not questioned in the Supreme Court of Canada." Shell's contention was derived from the introductory portion of clause 1:

1. In this Lease, unless there is something in the subject or context inconsistent therexith, the expressions following shall have the following meanings, namely:" ":8

Mr. Justice Marcland found that nothing in the subject or context of clause 3 was inconsistent with giving to "said lands" its defined meaning." But was it not really clause 9 and Shell's pooling thereunder which was inconsistent with the defined meaning of "said lands"? Clause 1 commences by stating that the defined meaning shall prevail "unless there is something in the subject or context inconsistent therewith". The neat question is is "the subject or context of what, the lease as a whole or the clause in which "said lands" appears? Mr. Justice Martland apparently chose the latter alternative. Yet clause 1 operfs with the words-"In this Lease,". Moreover, clause 3 was only relevant in the Gunderson case when read in conjunction with the pooling provisions of clause 9. Shell's argument was not without merit but the Supreme Court of Canada was confronted with two possible interpretations and its choice is now a matter of record.

One might be inclined to write off the Gunderson case as turning solely on defective draftmanship in the lease. It is yet another example in a long line of strict interpretation in favour of the lessor. ${ }^{.0}$ At this point, it might be asked

2s[1960] S.C.R. 424, at p. 429 et seq.

24Shell's argument on this point does not seem to have been clearly stated in the reasons for judgment.

2isupra, footnote 20.

2:[1960] S.C.R. 424, at p. 426. The italics are mine.

zolbid., at p. 430. His exact words were: "However, I cannos see anyehing in the subject or context of clause 3 which is inconsistent with giving to the expression "said lands" its defined meaning in that clause." He concluded the next paragraph which dealt with this same question by stating: "The subject and context of clause 3 in which the words "said lands" appear remain the same. There is not, in my view, anything contained in clause 9 sufficient to provide that the existence of a non-producing gas well on some part of the unit, other than the quarter section, shall have the same effect in extending the terms of the lease as though it were upon the quarter section itself." It is difficult to tell whether this last sentence pertains to the previous argument in the paragtaph or whether it is a general summation of the reasons for judgment as a whole since the next and last paragraph of the judgment is only a brief stacement of the result.

snSummers, The Law of Oil and Gas (1959) vol. 2, \$372, p. 485 ct seq. says concerning the rule of construction that oil and gas leases are to be construed in favour of the lessor and against the lessee: "While this expression is quite common in the opinions, it is submitted that while viewed as a statement of fact it may be true enough, but that viewed as a rule of construction it has no sound foundation." Summers' argument in this regard is summarized in Lewis and Thompson, op. cit., supra, footnote 6, vol. 1, div. A., $\$ 100$. Summers concludes: "If a court has carefully studied the evolution of the various clauses of the oil and gas lease from the beginning of the industry, understands their purpose, and the limitations which have been placed upon them from time to time by judicial decisions, is fully cognizant of the social and economic policy respecting the production of oil and gas as exemplified by current legislative enactment, he is far more capable of rendering justice to all concerned in the construction of an oil and gas lease than if he merely applies some often repeated rulc of construction of such instruments." 
why the courts do not look upon an oil and gas lease as a commercial contract to be construed liberally in order to carry out the object of the parties? This rather fundamental question was settled long ago in favour of the lessor in U.S. jurisdictions and Canadian courts have apparently accepted the same point of view." In the great majority of instances there is in fact little room for bargaining on the terms of a lease beyond the amount of the bonus, royalty and delay rental, if then. A lengthy printed form is placed before the lessor, the appropriate blanks are filled in and he signs. That he fails to appreciate the complexities of the document in almost every case is beyond doubt. This in itself would not seem to warrant such strict interpretation against the lessee. It is the one-sided content of the lease which has moved the court to intervene on behalf of the lessor. Not only has a strict approach been taken to interpretation of the lease. In many instances U.S. courts have found implied covenants between the parties nothwithstanding attempts by the lessee to exclude them by express provision in the lease to the contrary. are often unhappy with this situation but perhaps they are the authors of their own misfortune until they are willing to come together and draft a standard form of lease which is fair in its provisions to the lessor. Not until then can they expect a liberal interpretation of leases along the lines of commercial contracts. - In the meantime, Canadian courts will continue to construe leases strictly and as a result in favour of the lessor. ${ }^{33}$

\section{In The Supreme Court of Alberta, Appellate Division}

Whereas the decision in the Supreme Court of Canada rested solely upon the inadequacy of the lease provisions, the reasons for judgment on appeal in Alberta raised a number of interesting questions in addition to finding that the lease provisions relating to pooling did not cover the Gunderson situation. ${ }^{34}$ Mr. Justice Porter, in the course of his judgment stated:

"While there are a number of considerations that cast doubt on the right of Shell to pool as it has done, an examination of the existing situation may usefully be made on the assumption that the right to pool exists."3s

And later:

"Having disposed of the issue before us on the foregoing grounds, it becomes unnecessary co consider the very serious questions as to whether in the circumstances there is any lawful right to peol, so as to excuse drilling, having regard to the provisions of The Oil and Gas Conservation $A \mathrm{ct}, 1950$, ch. 46 and the purposes for which sec. 3 thereof declares it was passed.":in

$1950 "$.

This oblique teference to the 1950 Act is hardly very enlightening in itself. A perusal of the 1950 Act will fail to reveal any provision directly governing pooling although certain sections relating to spacing, drilling and production may indirectly affect voluntary pooling. ${ }^{37}$ It will be noted however that $\mathrm{Mr}$. Justice Porter has limited his remarks on this point to "in the circumstances".

al In addition to Summers, ibid., see Thornton, The Law of Oil and Gas (1932 with 1953 supp.) vol 1, \$ 132, p. 238 et seq. Canadian Fina Oil Lid. v. Paschke (1957) 21 W.W.R. 260, at p. 263 (Alta. C.A.) among others, indicates the position of Canadian courts.

iasec Merrill, op. cit., supra, footnote 4.

3:'Lewis and Thompson, op. cit., supra, footnote 6, vol. I, div. A, \$100.

a. (1958) 28 W.W.R. 506 (Alta. C.A.).

subid, at p. 510 .

36Ibid. The name of the Act should read: "The Oil and Gas Resources Conservation Act,

3isee for example, sections 20,30 and 34. The 1950 Act has now been repealed and replaced by The Oil and Gas Conservation Act, 1957 (Alta.), c. 63. 
In answer to the question of what "circumstances" relate the Gunderson situation to the 1950 Act, clause 9 of the lease gives the lessee the right to pool "when such pooling or combining is necessary in order to conform with any

- regulations or orders of the Government of the Province of Alberta or any other authoritative body, which are now or may hereafter be in force in relation thereto." ${ }^{3 x}$ In fact, Drilling and Production Regulations under the 1950 Act required a normal spacing unit of one section for a gas well. ${ }^{\text {:9 }}$ Presumably Shell relied on these Regulations in purporting to pool under clause 9. If it was not necessary to pool in June of 1955 in order to conform with government regulations or orders however, Shell may not have had the right to pool. This argument was fully developed a short while later by this same Court in Shell Oil Company v. Gibbard." Otherwise it is difficult to draw any substantial conclusion from Mr. Justice Porter's remarks. ${ }^{\text {.1 }}$

Chief Justice Ford, while concurring with Mr. Justice Porter, made additional observations. " He first referred to the primary term of 5 years in the habendum clause, with provision for extension "so long thereafter as the leased substances or any of them are produced from the said lands". A subsequent proviso permitted extension of the lease beyond the 5 year term if "the lessee is then engaged in drilling or working operations thereon" and so long as any production resulting therefrom continued. The Chief Justice then commented:

"In my view this supports the interpretation that the intention of the parties was that the primary term of five years could be extended only if the leased substances were being produced, or, if not, that drilling or working operations were then engaged in. It follows that even if clause 9 could be invcked by the appellant, it cannot assist in extending the primary term." 13

One possible inference from this passage is that a capped gas well even if it were on the Morris lands would not amount to "leased subtances ... produced from the said lands" as required by the habendum clause to extend the primary term. Clause 9 labours under the same difficulty since it specifically states that: "Drilling operations on, or production of leased substances from, any land included in such unit shall have the same effect in continuing this Lease in force and effect during the term hereby granted or any extension thereof, as to all the said lands, if such operation or production were upon or from the said lands, or some portion thereof." At At this point, clause 3 of the lease becomes relevant. It would be argued that the lease must be read as a whole

${ }^{38}$ The italics are mine. Clause 9 is set forth in full, supro, at p. 483.

34They art set forth so far as relevant in Shell Oil Company v. Gibbard (1961) 26 D.L.R. (2d) 400, at p. 404; (1961) 34 W.W.R. 117, at p. 121 (Alta. C.A.).

40(1961) 26 D.L.R. (2d) 400, at p. 403; (1961) 34 W.W.R. 117, at p. 120 (Alta. C.A.), discussed infra, at p. 491 et seq.

41Section 3 referred to at the end of the passage describes the intent, purpose and object of the 1950 Act in the most general of terms. It would seem that, far from being contrary to the aims of conservation there stated, Shell's purported pooling would be in accordance with them. Lewis and Thompson, op. cir., supra, footnote 6, vol. 1, div. A, s. 117 offer the following explanation: "The court must be referring to pooling after drilling and production, and probably alludes to the purpose stated in 3.3 (now 3. 4) of affording to each owner the opportunity of obtaining his just and equitable share of the production of oil and gas. It is difficult to conceive how the pooling clause, whether authorizing pacling before or after drilling, results in inequality in view of the usual apportionment of royalty provisions, and when it is realized that pooling is necessitated by spacing regulations, which are measures for the prevention of both economic and physical waste, it seems improbable that the Act should restriet the right to stipulate a pooling clause in the lease."

42 (1959) 28 W.W.R. 506 (Alta. C.A.).

49/6id., at p. 507.

"Clause 9 is rendered in full, infra, next page. The italiss are mine. 
and that clause 3 covers the situation where a gas well is capable of production but no market is immediately available. But does it? Clause 3 provides that a capped gas well in these circumstances "shall be deemed to be a producing well hereunder"." The question remains whether "a producing well" deemed under clause 3 satisfies the requirement of "leased substances ... p produced from the said lands" set forth in the habendum cla:sse. Likewise the pooling provision in clause 9 requires "production of leased substances". In view of the strict judicial interpretation of leases, it would appear that habendum, shutin royalty and pooling clauses should take into account these defects if the lessee wishes to protect himself against the possible consequences.

Secondly, the Chief Justice considered the time of pooling:

"Furthermore, in my opinion, the I-ase contemplated that pooling, if resorted to, should be decided upon prior to drilling fo: the purpose of forming a drilling unit so as to develop the area included in the unit, and this would include selecting the site for the well. It did not contemplate combining this land with other land, although contiguous, af ter a well had been drilled en such other land. To allow this would be to destroy the purpose contemplated by the parties," 4 s

What the lease contemplated in this regard can best be determined by examination of clause 9.

"9. The Lessee is hereby given the righe and power at any time and from time to time to pool or combine the said lands, or any portion thereof, with other lands adjoining the said lands, but so that any one such pool or unit (herein referred to as a 'unit') shall not exceed one drilling unit as hereinbefore defined, when such pooling or combining is necessary in order to conform with any rcgulations or orders of the Government of the Province of Alberta or any other authoritative body, which are now or may hereafter be in force in relation thereto. In the event of such pooling or combining, the Lessor shall, in lieu of the royalties elsewhere herein specified, receive on production of leased substances from the said unit, only such portion of the royalties stipulated herein as the area of the said lands placed in the unit bears to the total area of lands in such unit. Drilling operacions on, or production of leased substances from, any land included in such unit shall have the same effect in continuing this Lease in force and effect during the cerms hereby granted, or any extension thereof, as to all the said lands, if such operation or production were upon or from the said lands, or some portion thereof." + ?

The phrase "at any time and from time to time" would seem to indicate that pooling might be pursued either before, during or after drilling, provided of course that it was necessary in order to conform with the prescribed regulations or orders. ${ }^{48}$ If the only time that it was necessary to pool in order to conform to government regulations was to meet spacing requirements prior to drilling, then the Chief Justice's observation would be quite correct."

In the opinion of the Chief Justice, "... the lease contemplated that pool. ing, if resorted to, should be decided upon prior to drilling for the purpose of forming a drilling unit so as to develop the area included in the unit ...". But clause 9 clearly distinguishes a "pool or unit" from a "drilling unit" by stating that the ". . pool or unit (herein referred to as a "unit) shall not excecd one drilling unit as hereinbefore defined. ..". Thus a "pool or unit"

1"See supra, at p. 484, where clause 3 is reproduced in full.

11:(1959) 28 W.W.R. 507, at p. 508 (Alia. C.A.).

TThe italics are mine.

4N'This proviso is discussed at lengh in commertion witl the Shell Oil Company v. Gibbard case, infra, at p. 491 et seg.

401 bid at p. 491.

soThe italics are mine. Netice that the Chief Justice first speaks of "a drilling unit", then immediately afterwards mentions "the unit". Is the word drilling implied in the reference to "the unit" or was it intended otherwise? The discussion which immediately follows in this article emphasizes the importance of the distinction between "drilling unit" and "unit" in clause 9 of the lease. 
formed under clause 9 need not necessarily be a "drilling unit". It may be less than a "drilling unit" but not more. This distinction is maintained throughout clause 9. Clause $1(b)$ of the lease defines a "drilling unit" as follows:

" "Drilling unit' shall mean a section, legal subdivision or other unit of land representing the minimum area in which any well may be drilled on or in the vicinity of the said lands as defined or prescribed by or under any law of the Province of Alberta now or hereafter in effect govering the spacing of petroleum and for natural gas wells."

Its nomenclature and definition indicate that a "drilling unit" will be of importance prior to drilling. Is it not a fair conclusion that a plain unmodified "unit", expressly differentiated in clause 9 of the lease from a "drilling unit", does not bear the same time limitation attached by the word "drilling"?

At the same time, it is interesting to note that Shell in its pooling notice to Gunderson stated that it ".. . hereby pools and combines ... so as to form a drilling unit as defined in the said lease ....": Clearly it was unnecessary for Shell to be concerned about a "drilling unit" at this stage since the drilling of the well had long been completed and drilling requirements presumably met at that time. However the lands subject to pooling here were equal in size to the normal "drilling unit" for gas wells and were so described. Where a lessee sets out to drill an oil well under quarter section spacing regulations and brings in a gas well normally requiring full section spacing, pooling with adjoining lands subsequent to drilling is a logical and forseeable consequence. Practically speaking, the concept of voluntary pooling was designed to apply to the many and varied situations which arise before and after drilling.": . Although each lease must be interpretted on its own merits, it would be a most unusual document which expressly or impliedly endeavoured to restrict pooling to the period before drilling.

\section{Shell Oil Company v. Gibbard}

This is the sequel to the Gunderson case. ${ }^{5 t}$ It concerned the southwest quarter of the same section and arose following the decision of the Supreme Court of Canada in Gunderson. The facts are slightly different. This lease was dated September 16, 1949 and its primary term ran for ten years instead of five. Notice of the purported pooling was also served upon Gibbard but it was dated August 2nd, 1955 whereas the notice to Gunderson bore the date June 22nd, 1955. It might be noted that the Gunderson lease was due to expire on its anniversary date of July 19th, 1955.:3 By 1959 a market had become available for gas from the capped well on the northwest quarter. An application was made to the Conservation Board on May 21st, 1959 by Devon-Palmer Oils Limited as successor in interest to Shell, for a special spacing unit consisting of the north half and Gibbard's southwest quarter of the section but

51'This definition will be found in [1960] S.C.R. 424, at p. 426, and (1959) 28 W.W.R. 506, at p. 510 (Alta. C.A.).

cylbid., at pp. 428, 508. The italics are mine.

:Myers, op. cit., suprs, footnote 4, at p. 33 et seq., explains why and in what circumstantes voluntaty pooling became a "practical necessity".

u. Supra, footnote 1. The Gibbard case is presently on appeal to the Supreme Court of Canada.

onFor the sake of clarity in identifying the Morris lease with the Gunderson case, the Morris lease has been termed "the Gunderson lease", Gunderson of course being the execuror of Morris' estate. Mr. Justice Johnson has done likewise in the Gibbard case. Concerning the time of expiry of this lease, see supra, footnote 16. Mr. Justice Johnson commented: "It is obvious that the sole purpose of pooling at that time was an attempt to continue the life of the Gunderson lease which was then about to expire.": (1961) 26 D.L.R. (2d) 400, at p. 404; (1961) 34 W.W.R. 117, at p. 121 (Alta. C.A.). 
excluding Gunderson's southeast quarter. ${ }^{: n}$ On the June 24th following, an order of the Board was issued creating the unit requested as of July Ist, 1959. Production commenced in July of that year and continued thereafter. Gibbard however refused all payments tendered as his share of the royalty, and claimed that the lease had expired at the end of its primary term on or before September 16 th, 1959."7

One again the same clause 9 of the Shell lease was before the Appellate Division. In this case however there was production prior to expiry of the primary term and the question was directed to the validity of the pooling itself. It will be remembered that the Supreme Court of Canada in the Gunderson case did not consider whether the pooling was invalid. It merely held that the Gunderson lease had expired since there was neither production from the pooled unit nor drilling in progress upon it, these being the only grounds under clause 9 for extending the primary term. . $^{\text {ix }}$

Mr. Justice Johnson in a thoughtful judgment held against Shell on two points." Firstly, he decided that since the pooling had become ineffective as to the Gunderson quarter, it could not be considered valid as to the remaining three quarters. ${ }^{30}$ This conclusion was expressly stated to have been reached without consideration of The Oil and Gas Resources Conservation Act, 1950 and Regulations thereunder." Although the reasons for his opinion were not fully spelled out, perhaps since Mr. Justice Johnson preferred to rely upon his second point, there would appear to be considerable merit in it. Does not the pooling provision contemplate the continued participation of all parties to the pooling? Nothing in clause 9 indicates otherwise and everything seems to be based upon this assumption. The withdrawal of one party may destroy the conditions upon which the pooling was founded. It might also be that without the lands of the departed party, there could not have bsen a pooling in the first place. This would surely militate against the pooling being valid for the remainder. Furthermore parties to a pooling may be prejudiced by the de. parture of one. It does not follow however that the loss of one party will necessarily prejudice the remainder since this will depend on subsequent events. For example, there could quite conceivably be a greater return to those still within the pooling since they might share the royalties which would have been paid to the departed party, depending of course on the circumtances. In the case at hand, it is not clear that Gibbard was adversely affected by the loss of the Gunderson quarter from the pooling. However it is doubrful whether Shell could have pooled in the first instance without the Gunderson quarter since a pooling of three quarter sections would not have been "necessary in order to conform with any regulations or orders" as laid down in clause 9 when a one

Boij Devon-Palmer Oils Limited was also included in the Gibbard action. The statutory name of the Board is the "Oil and Gas Conservation Baard": St. Alta. 1957, c. 63, s, 2 (a) and 6.

"Sce supra, footnote 16 concerning the exact time of expiry of a lease.

sx.Supra, footnote 20.

"WFord, C.J.A., Macdonald, Porter, Johnson and Sinitl, JJ.A. concurred with Mr. Justics Johnsen.

150)(1961) 26 D.L.R. (2d) 400, at p. 403; (1961) 34 W.W.R. 117, at p. 120 (Alta. C.A.) It may be that Mr. Justice Johnson's remarks on this point are merely obiter however in light of his reliance on the secend point.

"Aside from Mr. Justice Johnson's second point, could the 1950 Act and Regulations bear on this question in any other way? 
section spacing unit for a gas well was in fact required by the Regulations.":

The second ground, which Mr. Justice Johnson seemed to prefer, concerned the validity of the pooling at the time of its inception. In his opinion, the purported pooling of the four quarter sections in 1955 was not "necessary in order to conform with any regulations or orders of the Government of the Province of Alberta or any other authoritative body" as dictated by clause 9 , despite a Regulation stating that the normal spacing unit for a gas well was one section." ${ }^{\text {"3 }}$ After an examination of relevant statutory provisions and regulations," Mr. Justice Johnson concluded:

"It will be seen that spacing units are only requircd (as far as this appeal is concerned) where there are applications either (a) to drill any well, or (b) to undertake any producing operations. At the time the notice was given in 1955, a permit for drilling an oil well had been obtained for the well on the adjoining quarter which turned out to be a gas well only. As I have mentioned, there was no ready market for this gas and the well was shut in. There being then no intention to produce this gas there was no need to apply for a permit to produce the well. Under these circumstances, it could not be said (to quote the words in the lease) that pooling was 'necessary in order to conform with any regulations or order' ...."

It appears that the Court may have been labouring under a slight misapprehension at this point. The above passage distinguishes between (a) an applicatiton for a permit to drill a well, and (b) an application for a permit to produce this well. Section $17(1)$ in the 1950 Act was probably the source of this distinction. It said:

\footnotetext{
"17-(1) No person shall commence to drill any well or undertake any operations preparatery or incidental to the drilling of a well or continue any drilling operations or any producing operations unless a license has been issued and is in full force and effect."(si
}

As a matter of interpretation, it is perhaps arguable that section 17 (1) requircd a separate license for producing operations but the better view seems to be that "a license", meaning one only, was required for the activities described. In practice, only one license was ever granted by the Minister under the 1950 Act and this was issued prior to drilling. It was not necessary to obtain a second license for production."

Regardless of which interpretation is correct, the reasoning of Mr. Justice Johnson that nothing in the Act or Regulations required Shell to have a full section spacing unit at the time of the purported pooling would seem to apply. It is even questionable whether anything in the 1950 Act or Regulations required Shell to have a spacing unit of one section in order to produce gas from

B:Clause 9 is set forth, supra, at pp. 483 and 488 . Regulation 3(2) prescribing a normal spacing unit of one section for a gas well, applicable here, is set forth in: (1961) 26 D.L.R. (2d) 400 , at p. 404 ; (1961) 34 W.W.R. 117, at p. 121 (Alta. C.A.).

osIbid. He said: "I think is it obvious that the sole putpose of pooling at that time was an attempt to continue the life of the Gunderson lease which was then about to expire."

"llbid., at pp. 403 and 120 . The sections quoted from The Oil and Gas Resources Conservation Act, 1950, (Alta.), c. 46, as amended, were $17(1), 20(1)(2)$ and 30 (a). Drilling and Production Regulations $2(3)$ and $3(1)(a)(b)$ were also set forth.

un(1961) 26 D.L.R. (2d) 400, at p. 404; (1961) 34 W.W.R. 117, at p. 121 (Alta. C.A.)

"in The Oil and Gas Resources Conservation $A$ ct, 1950 (Alta.), c. 46.

"Sisction 17(1) was repeated in The Oil and Gas Conservation Act, 1957 (Alta), c 63, s. $18(1)$, with the change of one word only - the first "any" to "a". Mr. Justice Johnson pointed out that in the 1957 Act, section 22(1) refers to a "license for a well" whereas the corresponding section $20(1)$ in the 1950 Act spoke of a "license to drill a well." He concluded that under the 1957 Act a licence "would include the licence to produce": (1961) 26 D.L.R. (2d) 400 at p. 404; (1961) 34 W.W.R. 117, at p. 121. It is suggested however that a licence to produce was not required under the 1950 Act in the first place and the 1957 Act merely clarifies the position. 
the well.:* On the other hand, paragraph 2(3) of the Regulations provided that "The normal spacing unit for a gas well is one section, ...". If a lessee brought in a gas well unexpectedly instead of an oil well as Shell did, assuming that normal spacing applied, did the language of paragraph 2(3) by itself immediately require him to comply with the one section standard? ? $^{\text {io }}$ It seems arguable at least.

Perhaps it is worth noting that clause 9 of the Shell lease said "necessary in order to conform with any regulations or orders". If it had said "necessary in order to comply with any regulations or orders", a mandatory meaning could more easily be inferred. But does not the word "conform" convey the impression of voluntary action? If so, pooling under clause 9 could have been validly undertaken to bring Shell into line with regulations or orders despite the fact that there was no immediate necessity of so doing.

In the event of their 1955 pooling being declared invalid, Shell argued in the alternative that a new pooling of the remaining three quarter-sections had been effected. This contention rested upon the successful application to the Conservation Board for the special spacing unit consisting of these three quarter-sections, the Board's order becoming effective July 1, 1959. At this point the Gibbard lease had more than two months of its primary term still to run." Production commenced in the month of July, 1959 and continued during successive months. One wonders why Shell or Devon-Palmer Oils Limited did not pool the three quarter-sections with the customary pooling notice immediately following the Board order. Such a pooling might have covered the risk of the 1955 pooling being held invalid. Since a special spacing order had been obtained and production was imminent, previous objections

18 The 1957 Act likewise appears to be deficient in this regard. It will be observed in addition that neither Act indicates that the license is to be issued specifically for an oil well and for an oil well only, or that it is to be for a gas well. For example, the 1950 Act speaks of "a well to be drilled for oil or gas" [s. $18(5), 19(1)]$, "a license to drill a well for the recovery of oil or gas from a spacing unit" [s. 20(i)], and "to drill for and produce oil or gas from a well" [s. 20(3)]. In the 1957 Act, the phrases, "a well to be drilled for the purpose of obtaining oil or gas" [3. 20(1)] and "a license for a well for the recovery of oil or gas" $[s .22(1)]$ are used. One possible inference is that a license for a well includes both an oil well and a gas well within its scope. That is, once a license has been granted, it matters not whether an oil well or a gas well is brought in since the license cover either eventuality, even if a gas well has been drilled on a unit spaced for an oil well. As a result, gas pro. duction under the licence may p:oceed without concern about spacing so long as before drilling, one satisfied the spacing requirement for an oil well and therefore obtained a valid licence which henceferch enabled one to produce "oil or gas". This argument hinges on the interpretation of the word "or" as being conjunctive racher than disjunctive, a familiar problem of interpretation.

we Regulation 2(3) is fully stated in (1961) 26 D.L.R. (2d) 400, at p. 404; (1961) 34 W.W.R. 117, at p. 121 (Alta. C.A.).

ioIt will be perceived that if a lessee must comply with one section spacing, he will not be in serious difficulty if he holds all the leases within the spacing unit. Where two or more lessees are involved in the same spacing unit however, numerous problems arise. Some may not agree on the division of royalty proceeds; others may not have adequate pooling pro. visions in their leases. It was to meet situations of this nature that compulsory pooling provisions were enacted in The Oil and Gas Conserration Act, 1957 (Alta.) c. 63, s. 73 et seg.

iIt was dated Sepeember 16th, 1949 and ran for a primary term of 10 years: supra, at p. 489. 
would seem to have been overcome.": No such step was taken but Shell argued that either the Board order made after the hearing on the special spacing unit or the tendering of cheques for Gibbard's share of the royalty for July and August of 1959 constituted a declaration and notice of a new pooling. :3 Gibbard was present at the hearing and presumably received notice or a copy of the Board's order. However Mr. Justice Johnson pointed out that pooling under clause 9 was intended to be independent of the spacing order and to "be an overt act evidenced by notice or otherwise" on the part of Shell." It should perhaps be noted that the Board has authority under the 1957 Act to make a pooling order but did not do so on this occasion. "i So far as the tendering of royalty cheques was concerned, they were stated to have been paid "pursuant to pooling notice delivered under the said lease, dated August 2nd, 1955 " and thus could hardly have manifested a new pooling.

\section{The Future of Voluntary Pooling}

Although both the Gunderson and Gibbard cases turn on interpretation of a pooling clause in one specific lease, they illustrate the difficulties which lic ahead in the area of voluntary pooling. " cause lessees to reexamine pooling provisions in their own lease forms, many of which will have similar or other defects. Currently subsisting leases are beyond repair but new lease forms will undergo substantial changes. Yet voluntary pooling by its very nature will still be inadequate. The lessor may be prejudiced by its abuse. "i Lessees face uncertainty as to the validity of their pooling owing to the intricacies of lease interpretation. The public interest in conservation benefits only indirectly and haphazardly. What is the solution? The Oil and Gas Conscrvation Act of 1957 introduced pooling provisions whereby the Conservation Board may grant a pooling order under certain circumstances. ${ }^{\text {is }}$ Unfortunately these circumstances appear to exclude a pool-

i:Note the practical problems faced however in dealing with the rapidly moving Gunderson and Gibbard situations. Devon.Palmer made application to the Board for the special spacing unit on May 21, 1950. The judgment of the Supreme Court of Alberta, Appellate Division in the Gunderson case is dated June 18, 1959. The Board order was made on June 24, 1959 and became effective July 1, 1959. Production commenced in July, 1959. In the Supreme Court of Canada, the Gunderson case was heard on January 27 and 28, 1960 and judgment handed down on April 11, 1960. Perhaps it was thought inadvisable to pool again with the Gunderson case on appeal to the Supreme Court of Canada and the validity of the 1955 pooling possibly in question there.

7:(1961) 26 D.L.R. (2d) 400, at p. 405; (1951) 34 W.W.R. 117, at p. 122 (Alta. C.A.).

illbid. The phrase "by notice or otherwise" gives rise to speculation concerning what evidence of voluntary pooling other than notice will be sufficient.

$\therefore$ The reason why no pooling order was made here would appear to be that The Oil and Gas Conservation Act, 1957 (Alta.), c. 63 provides for a pooling order only when voluntary pooling is impossible. Section 73 (2) states: "The applicant in his application shall state ... (b) that an agrcement to operate the tracts as a unit cannot be made on reasonable terms, (c) particulars of the efforts made by him to obtain agteement to the operation as a unit of all tracts within the spacing unit, ...". Since agreement on pooling had already been reached within the leases in question here, it appears that the application requircments forestalled a pooling order. Note that a pooling order was made by the Board on October 27th, 1960 for the full section: Alta. Reg. 337/60. By this time the Gund crson case had been decided in the Supreme Court of Canada and presumably agreement among the parties could not be reached on pcoling the full section. See infra, foornote 79 also.

"It should be mentioned that the Gibbard case is presently on appeal to the Supreme Court of Canada.

i'See the examples in William et al, op. cit., supra, footnote 3, at p. 586 et seq.

inThe Oil and Gas Conservation Act 1957 (Alta), c. 63, s. 71 ct scq. 
ing order where voluntary pooling is possible. ${ }^{\text {in }}$ Would it not seem desirable to enable either lessor or lessee to make application for a pooling order regardless of whether or not the lease contains a pooling provision? Another alternative is to provide that all pooling must be pursuant to a Board pooling order. In any event, it appears that some form of statutory machinery is needed to remedy the present ills of voluntary pooling.

79See supra, footnote 75. The problem arises, as in the Gibbard case, where the validity of a voluntary pooling under certain leases is or would be doubtful. Can the Board determine this question? Otherwise the lessee must await the outcome of litigation in the courts, by which time his leases may well have expired. It is perhaps arguable that lack of agreement on pooling as required for an application under section 73 of the Act is evidenced whete the lessor at any time disputes the validity of a voluntary pooling under the lease. 